\title{
Factors affecting the performance of professional nurses in Namibia
}

\begin{tabular}{|c|c|}
\hline \multicolumn{2}{|c|}{$\begin{array}{l}\text { Authors: } \\
\text { Magdalene H. Awases }{ }^{1} \\
\text { Marthie C. Bezuidenhout }{ }^{2} \\
\text { Janetta H. Roos }{ }^{2}\end{array}$} \\
\hline \multicolumn{2}{|c|}{$\begin{array}{l}\text { Affiliations: } \\
{ }^{1} \text { Afro-Africa, Nursing and } \\
\text { Midwifery, World Health } \\
\text { Organization }\end{array}$} \\
\hline \multicolumn{2}{|c|}{$\begin{array}{l}{ }^{2} \text { Department of Health } \\
\text { Studies, University of South } \\
\text { Africa, South Africa }\end{array}$} \\
\hline \multicolumn{2}{|c|}{$\begin{array}{l}\text { Correspondence to: } \\
\text { Janetta Roos }\end{array}$} \\
\hline \multicolumn{2}{|c|}{$\begin{array}{l}\text { Email: } \\
\text { roosjh@unisa.ac.za }\end{array}$} \\
\hline \multicolumn{2}{|c|}{$\begin{array}{l}\text { Postal address: } \\
\text { PO Box 392, UNISA 0003, } \\
\text { South Africa }\end{array}$} \\
\hline \multicolumn{2}{|c|}{$\begin{array}{l}\text { Dates: } \\
\text { Received: } 10 \text { Apr. } 2012 \\
\text { Accepted: } 02 \text { Feb. } 2013 \\
\text { Published: } 19 \text { Apr. } 2013\end{array}$} \\
\hline \multicolumn{2}{|c|}{$\begin{array}{l}\text { How to cite this article: } \\
\text { Awases, M.H., Bezuidenhout, } \\
\text { M.C. \& Roos, J.H., 2013, } \\
\text { 'Factors affecting the } \\
\text { performance of professional } \\
\text { nurses in Namibia', Curationis } \\
\text { 36(1), Art. \#108, } 8 \text { pages. } \\
\text { http://dx.doi.org/10.4102/ } \\
\text { curationis.v36i1.108 }\end{array}$} \\
\hline \multicolumn{2}{|c|}{$\begin{array}{l}\text { Copyright: } \\
\text { (C) 2013. The Authors. } \\
\text { Licensee: AOSIS } \\
\text { OpenJournals. This wo } \\
\text { is licensed under the } \\
\text { Creative Commons } \\
\text { Attribution License. }\end{array}$} \\
\hline \multicolumn{2}{|l|}{ Read online: } \\
\hline 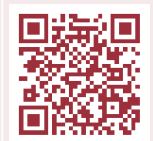 & $\begin{array}{l}\text { Scan this QR } \\
\text { code with your } \\
\text { smart phone or } \\
\text { mobile device } \\
\text { to read online. }\end{array}$ \\
\hline
\end{tabular}

Background: Professional nurses play a vital role in the provision of health care globally. The performance of health care workers, including professional nurses, link closely to the productivity and quality of care provision within health care organisations. It was important to identify factors influencing the performance of professional nurses if the quality of health care delivery was to improved.

Objectives: The aim of the present study was to identify factors affecting the performance of professional nurses in Namibia.

Method: A quantitative, descriptive survey was used to collect data by means of a questionnaire. A random sample of 180 professional nurses was selected from six hospitals in three regions of Namibia.

Results: Factors affecting the performance of nurses negatively were identified such as: lack of recognition of employees who are performing well, quality performance outcomes and an absence of a formal performance appraisal system and poor working conditions. Various factors contribute to both the positive and negative performance of professional nurses in Namibia. Strategies were developed for addressing the negative factors that could positively affect the performance of professional nurses in Namibia.

Conclusions: This study emphasises the importance of developing strategies to promote the performance of nurses; build knowledge and expertise; develop mechanisms for improving the performance of nurses; expand leadership and management capacity; and generate information and knowledge through research.

\section{Introduction}

Improving the productivity and performance of health care workers in order to enhance efficiency in health interventions, is a major challenge for African countries. Human resources for health (clinical and non-clinical) staff are paramount as staff is the most important asset of health systems. Performance of health care organisations depends on the knowledge, skills and motivation of individual employees. Employers should provide working conditions which support the performance of employees.

Health care workers are not producing the desired output in terms of health interventions, which is a concern for the World Health Organization (WHO) and policy- and decision-makers (High Level Forum 2004:1; World Bank 2000:5). Insufficient health personnel, in terms of numbers and performance level, are regarded as a major constraint in achieving the Millennium Development Goals (MDGs) for reducing poverty and diseases in many African countries. Proposed remedial actions include improving motivation, retention, productivity and the performance of health care workers, and mobilising unemployed trained staff, or those working in other areas, to return to the health sector (High Level Forum 2004:7; Stilwell 2001:2).

\section{Problem statement}

The quality, efficiency and equity of services depend on the availability of skilled, competent health professionals when and where they are needed. Health care workers need appropriate training to deliver the required standard of services. Interviews with nurses in Namibia indicated that nurses, comprising the backbone of health services, are overworked, demoralised, showing signs of burnout and complained about no recognition for their contributions (Awases et al. 2004:53; WHO 2003:18). Issues of performance and factors affecting performance are not adequately addressed in Namibia. Nurses have a major role to play in providing timely, quality health services as nurses and midwives comprise $80 \%$ of Namibia's health workforce (WHO 2011 accessed 16/12/2012). 
Factors affecting the performance of nurses in Namibia have not yet been examined. There is a need to seek evidence about nurses' performance and to develop strategies to monitor and improve their performance.

\section{Background}

Namibia, with a per capita income of $\$ 6250$ in 2008, exceeds the regional average of $\$ 2274$, but is below the global average of $\$ 10307$ (WHOSIS), with great inequality in the distribution of income. The economy depends mainly on mining such as; diamonds, uranium, gold, silver and copper (Namibia Government).

Identified health challenges and needs include timely, efficient health care services; poor human resource management; poor performance of health personnel resulting in poor quality of services; negative attitudes and low motivation of health care workers; and a general feeling of despondency amongst health care workers due to limited opportunities for career advancement and performance reward systems (WHO 2000:1). The importance of performance management in the health workforce is regarded as 'essential to improving efficiency, productivity and quality of care' (South Africa 2011).

There is presently no performance appraisal system in place for health services staff in Namibia, because the previous system was abandoned in 1998 (McCourt \& Awases 2005:7). Though the discontinued performance appraisal system was used ad-hoc in various disciplines in the Ministry of Health. Employers are supposed to ensure performance of a high standard by employees, or put measures in place to detect and rectify poor performance of first-line health care workers who are in contact with clients, patients and the community.

\section{Purpose of the study}

The purpose of the study was to identify and describe variables affecting the performance of professional nurses in Namibia.

\section{Objective}

The objective of this study was to determine factors which positively and negatively affect the performance of professional nurses in Namibia.

\section{Definition of key concepts}

Performance: Perform means 'to carry out, accomplish or fulfil an action or task'. It also means 'work, function, or to do something to a specific standard'. Performance is 'an action or process of performing a task or function' (Oxford Concise Dictionary 1999:1060). Important variables to be kept in mind are; function, work, action, task, process and specific standard. Performance is the actual conducting of activities to meet responsibilities according to standards. It is an indication of what is done and how well it is carried out (Winch, Bhattacharrya, Debay, Sariot, Bertoli \& Morrow 2003:2).
Performance appraisal is the 'process of observing and evaluating an employee's performance, recording the assessment, and providing feedback to the employee'. (Muller, Bezuidenhout \& Jooste 2011:564.)

Performance management in the context of staff management it 'is about helping people to work more effectively by improving individual and team performance, increasing the overall productivity of an agency'. (PSMPC 2000:1)

Professional nurse: A person registered with the nurse regulatory and registering authority of their country. Professional nurses are trained at higher education level with the training period between 3 and 4 years. Professional nurses, also called registered nurses, working in clinical nursing services and educational institutions.

Skill is the ability to perform a task, or a group of tasks, which often requires the use of motor functions, but also require specific knowledge and skills.

Work environment Characteristics of the environment in which a person is expected to work. The work environment includes physical and social environment, conditions of employment and benefits.

\section{Significance of the study}

The findings of this study identified factors that affect the performance of professional nurses in Namibia positively or negatively.

\section{Research method and design}

A quantitative approach was followed. A non-experimental descriptive survey, gathering data by means of a questionnaire was followed to collect data from professional nurses about factors that could influence their performance positively and negatively.

\section{Population and sampling}

The population for this study consisted of all professional nurses in Namibia. The target population for this study constituted professional nurses in public and private hospitals within the boundaries of the Oshana, Otjozondjupa and Khomas regions of Namibia.

The population consisted of 770 professional nurses, from which 180 (23.4\%) were randomly selected from a numbered staff list (excluding those on leave).

\section{Data collection method}

A self-administered questionnaire was designed in line with the objective and literature review, consisting of openand closed-ended questions. Respondents indicated their responses on a Likert scale for agreement levels ( $1=$ strongly disagree -5 = strongly agree), or from very poor to excellent, to measure their opinions, reactions and attitudes in relation to 
given statements (Polit \& Beck 2012:301). The questionnaires, together with a return envelope, were delivered personally by the researcher to the nursing manager of each hospital. During these visits the aim, importance of the study and questionnaire return dates, were explained. Of the 180 questionnaires that were distributed, 147 were returned.

\section{Data analysis}

Descriptive statistics that include frequencies and percentages were used for analysis of data. For the open-ended questions, data were organised under thematic categories and used in the discussions to support results from the close-ended questions. The statistical analysis programme SPSS was used to analyse the data.

\section{Ethical considerations}

Permission to do the study was acquired from the Permanent Secretary, Ministry of Health and Social Services of Namibia, as well as the medical superintendents of the participating hospitals.

Respondents were informed about the objective of the study, their voluntary participation and their right to withdraw from the study at any time. Anonymity and confidentiality were ensured by providing self-addressed envelopes with all questionnaires, requesting respondents not to write their names on the questionnaires.

\section{Validity and reliability}

Reliability of the instrument was determined by means of the Cronbach's Alpha, testing the internal consistency of items. The reliability of most items was adequate, whilst a few items such as; interpersonal relations, performance, commitment and satisfaction recorded a reliability of below 0.60 .

Content validity was achieved because a panel of experts composed of; experienced professional nurses, human resource managers, academics in nursing and a statistician, judged whether the instrument reflects the known content area. After proposing some changes, there was consensus amongst these experts that the instrument was valid for the study (Brink, Van der Walt \& Van Rensburg 2006:160; De Vos, Strydom, Fouche \& Delport 2005:161). The instrument was field tested prior to the use of the final document, after which the document was refined and some questions were rephrased.

\section{Discussion of results}

For the sake of the discussion, percentages of the positive values 'tend to agree and fully agree', 'strongly agree and agree' and 'good' and 'excellent' were combined. The same applies to the negative values.

\section{Biographical information}

Of the respondents $78.9 \%(n=116)$ were between $30-49$ years of age, $93.8 \%(n=138)$ were females and $71.4 \%(n=105)$ had diplomas in nursing and midwifery as their highest nursing qualifications. A third of the respondents $(35.4 \% ; n=52)$ had worked as professional nurses for 11-15 years and only $8.2 \%(n=12)$ of the respondents were working in private hospitals.

\section{Factors impacting positively and negatively on the performance of professional nurses \\ Knowledge and skills}

The majority of respondents perceived their knowledge and skills to be satisfactory on a number of items listed. Nursing audit received the highest score $(86.3 \% ; n=125)$, followed by planning of nursing care $(85.4 \% ; n=123)$ and interpersonal relations $(78.8 \% ; n=112)$. A third or less of the respondents rated themselves as average in providing in-service training $(34.7 \% ; n=50)$, patient counselling $(31.3 \% ; n=45)$, self-assessment with regard to performance outcomes $(24.5 \% ; n=35)$, and quality improvement $(21.9 \%$; $n=32$ ) (See Table 1). Roux and Halstead (2009:475) regard

TABLE 1: Knowledge and skills.

\begin{tabular}{|c|c|c|c|c|c|c|c|c|}
\hline \multirow[t]{2}{*}{ Knowledge and skills } & \multicolumn{2}{|c|}{ Poor } & \multicolumn{2}{|c|}{ Average } & \multicolumn{2}{|c|}{ Good } & \multicolumn{2}{|c|}{ Total } \\
\hline & $\%$ & $n$ & $\%$ & $n$ & $\%$ & $n$ & $\%$ & $N$ \\
\hline Planning of nursing care & 3.5 & 5 & 11.1 & 16 & 85.4 & 123 & 100 & 144 \\
\hline Implementing nursing care plans & 3.5 & 5 & 18.6 & 27 & 77.9 & 113 & 100 & 145 \\
\hline Nursing audit & 0.7 & 1 & 13.1 & 19 & 86.3 & 125 & 100 & 145 \\
\hline Implementing of nursing performance standards & 2.1 & 3 & 22 & 31 & 75.9 & 107 & 100 & 141 \\
\hline Health education & 5.5 & 8 & 10.3 & 15 & 84.1 & 122 & 100 & 145 \\
\hline Interpersonal relations & 2.8 & 4 & 18.3 & 26 & 78.8 & 112 & 100 & 142 \\
\hline Patient counseling skills & 7 & 10 & 31.3 & 45 & 61.8 & 89 & 100 & 144 \\
\hline Self-assessment with regard to outcome of performance & 0.7 & 1 & 24.5 & 35 & 74.8 & 107 & 100 & 143 \\
\hline Supervision of nursing care & 3.4 & 5 & 13 & 19 & 83.5 & 122 & 100 & 146 \\
\hline Supervising student nurses & 1.4 & 2 & 15.8 & 23 & 82.8 & 121 & 100 & 146 \\
\hline In-service training & 9 & 13 & 34.7 & 50 & 56.2 & 81 & 100 & 144 \\
\hline Management of time & 4.1 & 6 & 20.7 & 30 & 75.1 & 109 & 100 & 145 \\
\hline Maintaining facilities, equipment and supplies & 5.5 & 8 & 16.4 & 24 & 78.1 & 114 & 100 & 146 \\
\hline
\end{tabular}

$N$, Given as total number; $n$, Given as number. 
nurses as knowledge workers, 'taking information from many sources and combining it in meaningful ways'. These skills are essential for improving the quality of care, supervising students and providing in-service training to address the skills gap in the clinical wards.

\section{Performance appraisal and utilisation thereof}

More than a third $(38.1 \% ; n=56)$ of the respondents indicated that their performance were not reviewed and 19.1\% $(n=28)$ indicated that the reviews took place in an informal and ad hoc manner when there was a performance problem. Of the respondents $52.2 \%(n=77)$ said the results of performance appraisals were not used, whilst $17.7 \%(n=26)$ and $14.3 \%$ $(n=21)$ said that they were used for promotion and training respectively. Roussel and Swansburg (2009:553) indicated that monitoring of performance enhance commitment and productivity. Appraisals also motivate and re-enforces those who are performing well and should be seen as a continuous process.

Although $40.6 \%(n=58)$ of the respondents agreed that expected performance standards were clearly understood, $28.5 \%(n=41)$ disagreed. Sixty-one percent $(n=86)$ of the respondents disagreed that constructive feedback on appraisals was provided on a regular bases and 55.3\% $(n=$ 79) disagreed that feedback on how staff were performing, was provided throughout the year (See Table 2).

\section{Remuneration, benefits, reward and recognition}

Respondents disagreed that remuneration was competitive with other organisations $(47.6 \% ; n=69)$; that it was awarded according to experience $(49.6 \% ; n=72)$, or according to their job responsibilities $(52.5 \% ; n=75)$.

Some professional nurses were happy with their remuneration. However, $48.3 \%(n=70)$ did not feel that hardworking nurses are recognised. Some of the participants reported their opinion relating to remuneration as follows on the relevant open-ended question:

'I reached my maximum salary scale and remained at the scale for that last 5 years and I will remain at the scale for the next 20 years, unless there is an increment for all civil servants ... Remuneration does not compare well with other organisations. We are doing more work than others, but is paid less'. (Female, professional nurse, age unknown)

More than half of the respondents 54.6\% $(n=77)$ were dissatisfied with their fringe benefits and remarked that 'There are no other benefits, except for housing subsidy allowances ... The benefits are not clearly explained to us'. (Female, professional nurse, age unknown)

The majority $(75.9 \% ; n=110)$ disagreed that hardworking nurses were recognised, and $47.9 \%(n=67)$ disagreed that opportunities existed for career advancement (See Table 3). This is substantiated by the following responses:

TABLE 2: Performance appraisal and utilisation of results.

\begin{tabular}{|c|c|c|c|c|c|c|c|c|}
\hline \multirow[t]{2}{*}{ Performance appraisal and utilisation of results } & \multicolumn{2}{|c|}{ Disagree } & \multicolumn{2}{|c|}{ Uncertain } & \multicolumn{2}{|c|}{ Agree } & \multicolumn{2}{|c|}{ Total } \\
\hline & $\%$ & $n$ & $\%$ & $n$ & $\%$ & $n$ & $\%$ & $N$ \\
\hline Objectives to be achieved are known by individuals to be assessed & 28.5 & 41 & 29.9 & 43 & 41.6 & 60 & 100 & 144 \\
\hline $\begin{array}{l}\text { Performance standards expected from staff are clear and } \\
\text { understood by all }\end{array}$ & 32.2 & 46 & 27.3 & 39 & 40.6 & 58 & 100 & 143 \\
\hline $\begin{array}{l}\text { Constructive feedback on performance appraisal results is provided } \\
\text { on a regular basis }\end{array}$ & 61 & 86 & 16.3 & 23 & 22.7 & 32 & 100 & 141 \\
\hline $\begin{array}{l}\text { Feedback on how staff is performing is provided throughout the } \\
\text { year }\end{array}$ & 55.3 & 79 & 21 & 30 & 23.8 & 34 & 100 & 143 \\
\hline $\begin{array}{l}\text { Prompt action is taken when performance falls below acceptable } \\
\text { standards }\end{array}$ & 37.1 & 53 & 28.7 & 41 & 34.3 & 49 & 100 & 143 \\
\hline My manager or supervisor inspires me to do my best & 36.2 & 52 & 16 & 23 & 47.9 & 69 & 100 & 144 \\
\hline $\begin{array}{l}\text { Staff are given opportunity to make comments on the results of } \\
\text { their performance }\end{array}$ & 44.4 & 64 & 13.2 & 19 & 42.4 & 61 & 100 & 144 \\
\hline
\end{tabular}

$N$, Given as total number; $n$, Given as number.

TABLE 3: Remuneration, benefits, reward and recognition

\begin{tabular}{|c|c|c|c|c|c|c|c|c|}
\hline \multirow[t]{2}{*}{ Remuneration, benefits, reward and recognition } & \multicolumn{2}{|c|}{ Disagree } & \multicolumn{2}{|c|}{ Uncertain } & \multicolumn{2}{|c|}{ Agree } & \multicolumn{2}{|c|}{ Total } \\
\hline & $\%$ & $n$ & $\%$ & $n$ & $\%$ & $n$ & $\%$ & $N$ \\
\hline $\begin{array}{l}\text { Your remuneration is competitive compared to other similar } \\
\text { organizations }\end{array}$ & 47.6 & 69 & 27.6 & 40 & 24.9 & 36 & 100 & 145 \\
\hline Remuneration is in accordance with your job responsibility & 52.5 & 75 & 18.2 & 26 & 29.4 & 42 & 100 & 143 \\
\hline Fringe benefits are known to you & 34.2 & 46 & 26.4 & 37 & 39.2 & 55 & 100 & 140 \\
\hline You are satisfied with your fringe benefits & 54.6 & 77 & 26.2 & 37 & 19.1 & 27 & 100 & 141 \\
\hline Hardworking nurses are recognised & 75.9 & 110 & 14.5 & 21 & 9.6 & 14 & 100 & 145 \\
\hline $\begin{array}{l}\text { I receive prompt acknowledgement and recognition for doing a } \\
\text { good job }\end{array}$ & 55.1 & 81 & 21.1 & 31 & 23.8 & 35 & 100 & 147 \\
\hline I find my work rewarding & 47.1 & 53 & 21.7 & 31 & 41.3 & 59 & 100 & 143 \\
\hline The work I do gives me a feeling of personal achievement & 11.6 & 17 & 9.5 & 14 & 78.9 & 116 & 100 & 147 \\
\hline $\begin{array}{l}\text { When I retire I will receive a reasonable pension from this } \\
\text { organisation. }\end{array}$ & 18.4 & 27 & 38.1 & 56 & 43.5 & 64 & 100 & 147 \\
\hline
\end{tabular}

$N$, Given as total number; $n$, Given as number. 
'I am a registered nurse for 21 years and get the same salary as a person/registered with 5-10 years' experience ... even if you study and have a degree you are just getting the same salary as the person who has only a general nursing diploma'. (Female, professional nurse, age unknown)

Cowen and Moorhead (2011:161) also acknowledged that 'salary and benefits were the main causes of the [nursing] shortage'. The lack of a good and fair performance appraisal can also be regarded as a source of dissatisfaction, causing them to resign.

The majority of respondents agreed that the work they are doing gives them a feeling of personal achievement (78.9\%; $n=116$ ). They were less in agreement with the statements that they will receive a reasonable pension from the organisation on retirement $(43.5 \% ; n=64)$, and that they found their work rewarding $(41.3 \% ; n=59)$. The majority $(50.3 \% ; n=74)$ were of the opinion that their pay are not competitive with other similar organisations.

\section{Staffing and work schedules}

Some respondents disagreed with fairness of work schedules $(43.8 \% ; n=63)$, whilst $34.7 \%(n=50)$ agreed. Of the respondents $59.3 \%(n=86)$ disagreed that sufficient staff is allocated to cover the workload and stated:

'Shortage of staff, especially with a huge workload much more than the available staff ... Most nurses sometimes work beyond their scope of practice due to shortage of medical practitioners'. (Female, professional nurse, age unknown)

Letvak and Buck (2008:163) indicated that an increase in the workload resulted in increased absenteeism and a decrease in quality of care. The High-Level Forum on Health MDGs (2004:3) and Erasmus and Brevis (2005:54) confirm that staff shortages are constraints for delivering health care services.

\section{Staff development}

Staff development programmes in organisations are designed to ensure that staff knowledge and skills are developed, strengthened and kept up to standard, ensuring excellent care (Muller et al. 2011:366; Price 2000:348). Respondents disagreed that opportunities for advancing in the organisation $(45.8 \% ; n=66)$, continuing education $(42.1 \%$; $n=61)$, job specific refresher courses $(48.2 \% ; n=67)$ and good leadership and management training $(51.4 \% ; n=74)$ were available. The rest of the respondents either indicated that they were uncertain, or agree, with these statements. An even larger percentage $(61.8 \% ; n=89)$ of respondents disagreed that incompetent nurses were identified and provided with the necessary support (See Table 4).

During the appraisal interview, the manager should establish deficiencies in the knowledge and skills of employees and address these through creating staff development opportunities (Muller et al. 2011:350).

\section{Workspace and environment}

More than a half of the respondents $(57.5 \% ; n=81)$ disagreed with the availability of the necessary instruments, that the instruments were in working condition (56.7\%; $n=81$ ) and sufficient materials and supplies were available $(61.8 \% ; n=89)$. Responses to open-ended questions on professional nurses' desired improvements included; 'maintaining of facilities and equipment', 'modern equipment needed' and 'speedy repair of equipment'.

Most respondents agreed that infection control guidelines were available $(66.6 \% ; n=96)$, as well as antiseptic hand solutions for protection of staff and patients $(62.5 \% ; n=90)$. Half of the respondents $50 \%(n=71)$ disagreed with the statement that the work environment was safe and hazard free, whilst $19 \%(n=27)$ were uncertain and $31 \%(n=44)$ agreed (See Table 5).

TABLE 4: Staff development.

\begin{tabular}{|c|c|c|c|c|c|c|c|c|}
\hline \multirow[t]{2}{*}{ Staff development } & \multicolumn{2}{|c|}{ Disagree } & \multicolumn{2}{|c|}{ Uncertain } & \multicolumn{2}{|c|}{ Agree } & \multicolumn{2}{|c|}{ Total } \\
\hline & $\%$ & $n$ & $\%$ & $n$ & $\%$ & $n$ & $\%$ & $N$ \\
\hline Opportunities for advancing in the organisation exist & 45.8 & 66 & 28.5 & 41 & 25.7 & 37 & 100 & 144 \\
\hline Good opportunities for continuing education are available & 42.1 & 61 & 24.8 & 36 & 33.1 & 48 & 100 & 145 \\
\hline The necessary training is given to ensure job effectiveness & 26.9 & 39 & 37.2 & 54 & 35.8 & 52 & 100 & 145 \\
\hline Job specific refresher courses are available & 48.2 & 67 & 26.6 & 37 & 25.2 & 35 & 100 & 139 \\
\hline In-service training adequately addresses the skill gap & 35.1 & 51 & 32.4 & 47 & 32.4 & 47 & 100 & 145 \\
\hline $\begin{array}{l}\text { Incompetent nurses are identified and provided with the necessary } \\
\text { support }\end{array}$ & 61.8 & 89 & 21.5 & 31 & 16.7 & 24 & 100 & 144 \\
\hline Good leadership or management training available & 51.4 & 74 & 29.2 & 42 & 19.5 & 28 & 100 & 144 \\
\hline $\begin{array}{l}\text { Professional nurses participate in identifying their staff } \\
\text { development needs }\end{array}$ & 40.7 & & 21.4 & 31 & 37.9 & 55 & 100 & 145 \\
\hline
\end{tabular}

$N$, Given as total number; $n$, Given as number.

TABLE 5: Workspace and environment.

\begin{tabular}{|c|c|c|c|c|c|c|c|c|}
\hline \multirow[t]{2}{*}{ Workspace and environment } & \multicolumn{2}{|c|}{ Disagree } & \multicolumn{2}{|c|}{ Uncertain } & \multicolumn{2}{|c|}{ Agree } & \multicolumn{2}{|c|}{ Total } \\
\hline & $\%$ & $n$ & $\%$ & $n$ & $\%$ & $n$ & $\%$ & $N$ \\
\hline My work environment is safe and free from hazards & 50 & 71 & 19 & 27 & 31 & 44 & 100 & 142 \\
\hline Good workplace layout & 32.8 & 40 & 30.3 & 37 & 36.9 & 45 & 100 & 122 \\
\hline Necessary instruments are available & 57.5 & 81 & 9.9 & 14 & 32.6 & 46 & 100 & 141 \\
\hline Instruments in working condition & 56.7 & 81 & 11.2 & 16 & 32.2 & 46 & 100 & 143 \\
\hline Materials and supplies sufficient & 61.8 & 89 & 13.2 & 19 & 25 & 36 & 100 & 144 \\
\hline $\begin{array}{l}\text { Antiseptic hand solution for protection of staff and patients is } \\
\text { available }\end{array}$ & 27.8 & 40 & 9.7 & 14 & 62.5 & 90 & 100 & 144 \\
\hline Infection control strategy guidelines available & 18.1 & 26 & 15.3 & 22 & 66.6 & 96 & 100 & 144 \\
\hline
\end{tabular}

$N$, Given as total number; $n$, Given as number. 
The physical conditions were not conducive to work, constraining employees in providing quality care. This was confirmed by Cowen and Moorhead (2011:15) and Meessen, Kashala and Musango (2007:108) indicating that unavailability of equipment, searching for supplies and having to wait for medications are performance barriers.

\section{Organisational mission and goals}

Of the respondents $46.3 \%(n=68)$ agreed that the organisation's mission was understood by everyone, whilst $70.8 \%(n=104)$ agreed they understood what objectives had to be achieved and $51.7 \%(n=76)$ knew how their work contributed to the organisation's mission. (See Table 6). Bennett and Franco (1999:4), Nickols (2003:2) and Roussel and Swansburg (2009:289) also concluded that employees should know the organisation's goals and mission, as well as their own objectives and expectations in order to contribute to the overall goals of the organisation.

\section{Commitment and satisfaction}

There seems to be a sense of professional pride and vocation as indicated by the following responses when respondents either agreed or strongly agreed that doing this job makes them feel good about themselves $(78.6 \% ; n=114)$, that they were proud to tell people they work for this organisation $(65.8 \% ; n=96)$, that the organisation provided them with skills and knowledge that will benefit their future $(56.5 \%$; $n=83$ ) (See Table 7). Ahmad and Oranye (2010:584) regard organisational commitment as 'essentially about [their] attitude and behaviour towards shared goals of a group or organization'. Committed nurses might feel that there are future advantages in working as nurses for the organisation.

\section{Aspects related to leadership and management style}

Most respondents trusted and respected their immediate supervisors $(81 \% ; n=119)$, whilst $53.1 \%(n=78)$ were of the opinion that their managers and/or supervisors inspired them to do their best, and $36.8 \%(n=54)$ agreed that management always informed affected people about changes (See Table 8). Managers' leadership and management styles in the organisation have a significant effect on the performance outcomes of their subordinates. According to Booyens (2008:243) leadership competencies include the ability to build staff's capacity to perform at a high level through constructive feedback and development'.

\section{Implications for nursing management}

There were no official guidelines available to improve the performance of professional nurses in Namibia. The following strategies are proposed in the form of broad strategic actions to address the strengthening and performance of professional nurses:

- Building knowledge and competencies through continued professional development, in-service training programmes and clinical specialisation.

TABLE 6: Organisational mission and goals.

\begin{tabular}{|c|c|c|c|c|c|c|c|c|}
\hline \multirow[t]{2}{*}{ Organisational mission and goal } & \multicolumn{2}{|c|}{ Disagree } & \multicolumn{2}{|c|}{ Uncertain } & \multicolumn{2}{|c|}{ Agree } & \multicolumn{2}{|c|}{ Total } \\
\hline & $\%$ & $n$ & $\%$ & $n$ & $\%$ & $n$ & $\%$ & $N$ \\
\hline $\begin{array}{l}\text { Most people here know how their work contributes to this } \\
\text { organisation's mission }\end{array}$ & 30.6 & 32 & 17.7 & 26 & 52 & 76 & 100 & 147 \\
\hline $\begin{array}{l}\text { This organisation's mission is understood by everyone who works } \\
\text { here }\end{array}$ & 27.2 & 40 & 26.5 & 39 & 46 & 68 & 100 & 147 \\
\hline I am clear about the objectives I need to achieve & 8.2 & 13 & 21.1 & 31 & 71 & 104 & 100 & 147 \\
\hline People in this organisation have shared sense of purpose & 28.7 & 42 & 32.2 & 47 & 39 & 57 & 100 & 146 \\
\hline
\end{tabular}

$N$, Given as total number; $n$, Given as number.

TABLE 7: Commitment and satisfaction.

\begin{tabular}{|c|c|c|c|c|c|c|c|c|}
\hline Commitment and satisfaction & $\%$ & $n$ & $\%$ & $n$ & $\%$ & $n$ & $\%$ & $N$ \\
\hline I am proud to tell people that I work for this organisation & 18.5 & 27 & 15.8 & 23 & 65.8 & 96 & 100 & 147 \\
\hline I do not like the way this organisation operates & 30.6 & 45 & 33.3 & 49 & 36.1 & 53 & 100 & 147 \\
\hline $\begin{array}{l}\text { This organisation provides me with skills and knowledge that will } \\
\text { benefit my future career. }\end{array}$ & 18.3 & 27 & 25.2 & 37 & 56.5 & 83 & 100 & 147 \\
\hline Doing this job makes me feel good about myself & 10.3 & 15 & 11 & 16 & 78.6 & 114 & 100 & 146 \\
\hline I am subject to personal criticism or abuse at work & 52.1 & 74 & 22.5 & 19 & 25.3 & 36 & 100 & 142 \\
\hline I am constantly seeking out new challenges at work & 14.1 & 20 & 22.5 & 50 & 63.4 & 90 & 100 & 142 \\
\hline
\end{tabular}

$N$, Given as total number; $n$, Given as number.

TABLE 8: Management style of supervisors.

\begin{tabular}{|c|c|c|c|c|c|c|c|c|}
\hline \multirow[t]{2}{*}{ Leadership and management style } & \multicolumn{2}{|c|}{ Disagree } & \multicolumn{2}{|c|}{ Uncertain } & \multicolumn{2}{|c|}{ Agree } & \multicolumn{2}{|c|}{ Total } \\
\hline & $\%$ & $n$ & $\%$ & $n$ & $\%$ & $n$ & $\%$ & $N$ \\
\hline My manager or supervisor inspires me to do my best & 25.1 & 37 & 21.8 & 32 & 53.1 & 78 & 100 & 147 \\
\hline $\begin{array}{l}\text { When changes are made in the way things are done, management } \\
\text { always first informs the people who will be affected }\end{array}$ & 34 & 50 & 29.3 & 43 & 36.8 & 54 & 100 & 147 \\
\hline $\begin{array}{l}\text { If I have an idea for improving the way we do our work, my } \\
\text { supervisor or manager will usually listen to me }\end{array}$ & 22.4 & 33 & 38.1 & 56 & 39.5 & 58 & 100 & 147 \\
\hline $\begin{array}{l}\text { My manager or supervisor gives me regular, timely feedback that } \\
\text { helps me improve my performance }\end{array}$ & 46.7 & 54 & 31.3 & 46 & 32 & 47 & 100 & 147 \\
\hline $\begin{array}{l}\text { Senior managers in this organisation are open to new ideas and } \\
\text { suggestions }\end{array}$ & 41.5 & 61 & 27.9 & 41 & 30.6 & 45 & 100 & 147 \\
\hline I trust and respect my immediate supervisor & 2.7 & 4 & 16.3 & 24 & 81 & 119 & 100 & 147 \\
\hline
\end{tabular}

$N$, Given as total number; $n$, Given as number. 
- Developing mechanisms for performance enhancement of nurses by means of a formal performance appraisal system, the development of performance standards and the proper management of the nursing health workforce system.

- This performance management system should address aspects such as human resources in nursing, motivation, remuneration and incentives, recognition and rewarding of professional nurses, work conditions and environment and increasing the numbers of nursing cadres.

- Development of leadership and management capacity through leadership development and management programmes, courses in interpersonal relations, communication and supportive supervision.

\section{Limitations of the study}

- Some of the older Afrikaans speaking nurses might have encountered some language difficulties with the English terminology, as clarification was requested in Afrikaans about the meanings of some of the terms used in the questionnaire.

- All aspects related to factors affecting performance of professional nurses might not have been dealt with during this study. However this study results and the instruments developed might serve as a baseline for further research addressing aspects overlooked during this study.

- Due to the small number $(8.2 \% ; n=12)$ of respondents from private hospitals comparisons between public and private hospitals were abandoned.

- To ask respondents to determine their own perceived knowledge and skills is not the best method to obtain the data. The researcher had, however, no other way to determine it as she could not observe each respondent to determine it.

\section{Recommendations}

This study provides valuable feedback about the factors affecting the performance of professional nurses in Namibia. It is therefore recommended that the health services managers will implement the strategies developed above to improve the performance of the professional nurses employed in their institutions.

There is a gap in literature about performance management of health care workers in general and more specific professional nurses in Namibia and South Africa. Research in performance management is necessary to enhance the quality of health care delivery.

\section{Conclusion}

The purpose of the study was to identify and describe variables affecting the performance of professional nurses in Namibia. In this study the selected Namibian hospitals had deficiencies in managing human resources, implementing a performance appraisal system, staff and skills development and maintaining a conducive work environment. Regardless of the negative factors, the study affirmed nurses' commitment and professional pride, indicating that they were proud to be nurses despite all the problems constraining their work.

\section{Acknowledgements}

We wish to thank the Ministry of Health and Social Services of Namibia, as well as the medical superintendents of the participating hospitals, for granting permission for the study to be conducted. Every respondent who completed a questionnaire is thanked for his or her contribution, without which this research project could not be completed.

\section{Competing interests}

The authors have no competing interests to declare.

\section{Authors' contributions}

M.H.A. (WHO) conducted the study for her DLitt et Phil degree. M.C.B. (UNISA) was the supervisor and J.H.R. (UNISA) was the joint supervisor. M.H.A. obtained permission for the study and collected the data. M.C.B and J.H.R. guided the research process from conception until its conclusion. J.H.R. and M.C.B. assumed the major responsibility for getting the article written, based on the doctoral thesis, and for continuing with the process until publication, with inputs from the other authors when requested.

\section{References}

Ahmad, N. \& Oranye, N.O., 2010, 'Empowerment, job satisfaction and organizational commitment: a comparative analysis of nurses working in Malaysia and England', Journal of Nursing Management 18,582-591. http://dx.doi.org/10.1111/j.13652834.2010.01093.x, PMid: 20636507

Awases, M., Gbary, A., Nyoni, J. \& Chatora, R., 2004, Migration of health personnel in six countries: A synthesis report, World Health Organization, Regional Office for Africa, Brazzaville.

Bennett, S., \& Franco, L.M., 1999, 'Public sector health worker motivation and health sector reform: A conceptual framework', Major Applied Research 5, Technical Paper 1. Maryland, Partnerships for Health Reform Project, Abt Associates Inc.

Booyens, S.W. (ed.), 2008, Introduction to health services management, 3rd edn., Juta, Cape Town.

Brink, H., Van der Walt, C. \& Van Rensburg, G., 2006, Fundamentals of research methodology for health care professionals', 2 nd edn., Juta, Cape Town.

Cowen, P.S. \& Moorhead, S., 2011, Current issues in nursing, 8th edn., Mosby Elsevier, St Louis.

De Vos, A.S., Strydom, H., Fouche, C.B. \& Delport, C.S.L., 2005, Research at grass roots for the social sciences and human services professions, 3rd edn., Van Schaik Publishers, Pretoria.

Erasmus, B.J. \& Brevis, T., 2005, 'Aspects of working life of women in the nursing profession in South Africa: survey results', Curationis 28(2), 51-60. http://dx.doi. org/10.4102/curationis.v28i2.946, PMid: 1604511

High Level Forum on Health MDGs, 2004, Report: addressing Africa's health workforce crisis: an avenue for action, WHO, Geneva.

Letvak, S. \& Buck, R., 2008, 'Factors influencing work productivity and intent to stay in nursing. Nursing Economic\$26(3), 159-165. PMid: 18616053

McCourt, W. \& Awases, M., 2005, Report on health workforce 'innovative approaches and success stories' study (Unpublished).

Meessen, B., Kashala, J-P.I. \& Musango, L., 2007, 'Output-based payment to boost staff productivity in public health centres: contracting in Kabutare district Rwanda', Bulletin of the World Health Organization 85(2), 108-115. http://dx.doi. org/10.2471/BLT.06.032110, PMid: 17308731, PMCid: 2636284

Muller, M., Bezuidenhout, M. \& Jooste, K., 2011, Healthcare service management, 2nd edn., Juta, Cape Town.

Namibia, viewed 13 December 2012, from http://www.namibiagovernment.com/ economy.htm 
Nickols, F., 2003, 'Factors Affecting Performance', viewed 13 December 2012 from http://www.nickols.us/factors

Oxford Concise Dictionary, 1999, 10th edn., Oxford University Press, Oxford.

Polit, D.F. \& Beck, C.T., 2012, Nursing research generating and assessing evidence for nursing practice, 9th edn., Lippincott Williams \& Wilkins, Philadelphia.

Price, A., 2000, Principles of human resources management. An active learning approach, Blackwell Publishers Ltd., Oxford.

Public Service and Merit Protection Commission (PSMPC), 2000, Counselling for better work performance, Commonwealth of Australia, Canberra.

Roussel, L. \& Swansburg, R.C., 2009, Management and leadership for nurse administrators, 5th edn., Jones and Bartlett, Sudbury.

Roux, G. \& Halstead, J.A., 2009, Issues and trends in nursing. Essential knowledge for today and tomorrow, Sudbury, Jones and Bartlett, Sudbury.
South Africa, 2011, 'Human resources for health South Africa', HRH strategy for the health sector: 2012/13-2016/17, viewed 13 December 2012, from http://www. psyssa.com/documents/HRH

Stilwell, B., 2001, Motivation of health workers in Zimbabwe, WHO, Geneva (Unpublished paper).

World Bank, 2000, World development report 2000, Investing in health, The World Bank, Washington DC.

WHO, 2000, The world health report 2000. Health systems: Improving performance, World Health Organization, Geneva.

WHO, 2011, viewed 16 December 2012, from http://www.who.int/whosis/whostat WHOSIS (WHO Statistical Information System), Date, viewed 13 December 2012, from (http://www.who.int/whosis/en/)

Winch, P.J., Bhattacharyya, K., Debay, M., Sarriot, E.G., Bertoli S.A. \& Morrow, R.H., 2003, Improving the performance of facility- and community-based health workers, State-of-the-Art Series: Health Worker Performance, CSTS, Maryland. 